\title{
Abundance and Distribution of Cigarette Butts on Coastal Environments: Examples from Southern Spain
}

\author{
Francisco Asensio-Montesinos ${ }^{1,2}$ D, Milagrosa Oliva Ramírez ${ }^{3}$, María Teresa Aguilar-Torrelo ${ }^{1}$ \\ and Giorgio Anfuso 1,*(D)
}

1 Departamento de Ciencias de la Tierra, Facultad de Ciencias del Mar y Ambientales, Campus Río San Pedro s/n, Universidad de Cádiz, Puerto Real, 11510 Cádiz, Spain; francisco.asensio@uca.es (F.A.-M.); mariateresa.aguilartorrelo@alum.uca.es (M.T.A.-T.)

2 Instituto Multidisciplinar para el Estudio del Medio (IMEM), Universidad de Alicante, E-03080 Alicante, Spain

3 Departamento de Biología, Facultad de Ciencias del Mar y Ambientales, Campus Río San Pedro s/n, Universidad de Cádiz, Puerto Real, 11510 Cádiz, Spain; milagrosa.oliva@uca.es

* Correspondence: giorgio.anfuso@uca.es

check for updates

Citation: Asensio-Montesinos, F.; Oliva Ramírez, M.; Aguilar-Torrelo, M.T.; Anfuso, G. Abundance and Distribution of Cigarette Butts on Coastal Environments: Examples from Southern Spain. J. Mar. Sci. Eng. 2021, 9, 129. https://doi.org/

10.3390/jmse9020129

Academic Editor: Rodger Tomlinson

Received: 24 December 2020

Accepted: 23 January 2021

Published: 27 January 2021

Publisher's Note: MDPI stays neutral with regard to jurisdictional claims in published maps and institutional affiliations.

Copyright: (c) 2021 by the authors. Licensee MDPI, Basel, Switzerland. This article is an open access article distributed under the terms and conditions of the Creative Commons Attribution (CC BY) license (https:/ / creativecommons.org/licenses/by/ $4.0 /)$.

\begin{abstract}
Litter on beaches is one of the most difficult problems in coastal management and every year, much efforts and public money are invested to try to alleviate and solve the problem. Cigarette butts (CB) are among the most widespread abandoned personal items in the world. In Spain, they are found on all types of beaches, where they are discarded by beach users; however, rivers and streams can also deposit CB on shores. This paper analyses the abundance of CB on different beaches in Southern Spain in order to address and better understand this relevant environmental problem and propose sound solutions to decrease or eliminate their presence. The main factors favouring $\mathrm{CB}$ accumulation were identified, namely the seasonality and number of beach users, beach typology (remote, rural, village or urban sites), type of beach sediment and methods and frequency of cleaning operations. Mean and median CB abundance values per $100 \mathrm{~m}$ of beach length, calculated from all the data used in this study, were 159 and 68 items, respectively. The largest number of CB were observed at urban sites, followed by village, rural and remote beaches. Further, sand beaches registered higher values of $\mathrm{CB}$ than cobble or pebble beaches.
\end{abstract}

Keywords: Alacant; beach; Cádiz; Ceuta; cleaning efforts; marine litter; plastic pollution; smokers; tobacco product waste

\section{Introduction}

Litter is typically observed on almost all beaches and oceans around the world since it is able to reach most isolated areas of the planet, such as deep environments [1], e.g., the Mariana Trench [2], or extremely remote sites such as Antarctica [3,4]. Coastal systems receive litter from land-based sources (e.g., through rivers and sewerage systems) and from sea-based sources (e.g., fishing boats and infrastructures at sea) [5]. The presence of litter is also the result of intentional actions, e.g., when it is abandoned directly onto the beach by users such as beachgoers and fishers, among others [6]. Marine litter and associated contaminants have accumulated and transferred to biota in coastal areas, the open sea and the water column over several decades [7].

Within beach litter, cigarette butts (CB) constitute one of the most abundant items. The presence of this type of personal waste has been very well documented in different beaches around the world [8-13], including Spain [14-16]. Their presence on the coast can be used as an indicator of beach management efficiency [17], environmental consciousness [18] and beach pollution linked to beachgoers [19]. In addition, the presence of CB has an aesthetic impact on beaches [6] that can affect the "Sun, Sea and Sand" (3S) tourism [20]. Smoking is an activity that produces waste that comprises a large number of different materials: 
for example, from only one packet of cigarettes, various types of items are dumped on the beach: at least, 20 cigarettes filters made of cellulose acetate and tobacco, a cardboard cigarette packet, two pieces of inner foil packaging and, finally, two pieces of outer plastic packaging made of polypropylene (PP), all of which are very commonly found on beaches in Southern Spain [21].

Cigarette butts contain four main components: a filter, burned and unburned tobacco, ashes and paper. There are over 5000 compounds present in cigarettes, among these, at least 150 (of which 44 are found in large amounts) are considered to be highly toxic [22]. When burned, many of the chemicals present in cigarettes produce new compounds [23,24]. These compounds can contaminate the soil after leaching by rainwater and are superficially transported to aquatic environments where they can be detected [22].

Toxicity due to the presence of CB in aquatic environments has been demonstrated by numerous investigations including different marine species from unicellular organisms such as foraminifera [25] to larger ones such as invertebrates and fish [22,26]. Environmental groups have expressed concerns for marine creatures that ingest littered filters [8,27]. A laboratory study by Micevska et al. (2006) found that CB were found to be acutely toxic to a freshwater cladoceran organism and a marine bacterium and that the main cause of toxicity was attributed to nicotine and ethylphenol in their leachates [28]. Filter fibres are treated with titanium dioxide and packed using triacetin (glycerol triacetate). Most cigarette filters are surrounded by two layers of paper and/or rayon wrapping, which contain chemicals, such as glues to hold the paper together, and alkali metal salts of organic acids in order to maintain burning while the cigarette is being smoked [22]. Slaughter et al. (2011) showed that the toxicity of cigarette butt leachate increased from unsmoked cigarette filters (no tobacco) to smoked cigarette filters (no tobacco) to smoked CB (smoked filter + tobacco) [22]. They confirmed the toxicity of CB to fish and some other representative marine organisms such as daphnids and marine bacteria. Moreover, other studies have also shown that heavy metals and chemicals in cigarette butt leachate may be acutely toxic to marine species [29].

The occurrence of different metals in cigarettes is mainly attributed to the cultivation and growth of tobacco [30]. Insecticide, herbicides and pesticide application may also introduce metals to the tobacco leaf [31]. Further introduction of metals may occur during cigarette manufacture [32,33] or during the application of brightening agents on the wrapping paper [34]. The response of biota to the metals is extremely different according to the tolerance of each specie to the amount and type of metals present [35]. Furthermore, pesticides, which potentially remain in unsmoked cigarettes, may contribute to the toxicity of cigarette leachate. Ethylphenol is commonly used in the tobacco industry as a tobacco flavouring agent and is present in cigarette smoke [36]. Ethylphenol is bioaccumulated in aquatic organisms [22]. Chemical additives are often introduced to make tobacco products more attractive to consumers. For example, sugars and humectants make smoke milder and easier to inhale, humectants can prolong shelf life, ammonia may enhance the delivery of nicotine and menthol and eugenol effectively numb the throat [37]. Approximately 600 additives were in use by major American cigarette companies in 1994 [38].

Cigarettes discarded onto beaches can be ingested by children, domestic animals and wildlife, causing severe health risks [39]. Nicotine in tobacco products is rapidly absorbed by oral and intestinal mucosa and nicotine-related symptoms develop rapidly $(<4 \mathrm{~h})$ after ingestion. Symptoms include nausea, vomiting, salivation, convulsions, bradycardia with hypotension, cardiac arrhythmias and respiratory depression [40]. Reports of accidental ingestion of butts are not uncommon among children, especially those $<6$ years old [41]. In young children, 1-2 mg may be toxic, causing nausea and vomiting in low doses, and more extensive neurological symptoms with higher doses [42]. CB ingestion in wildlife (for example, marine turtles or sea birds) is rare but $C B$ ingestion in pets is frequent. In dogs, this ingestion can cause excessive salivation, excitement, tremors, vomiting, lack of coordination and weakness (signs have been reported at doses as low as $1 \mathrm{mg} / \mathrm{kg}$ ) [43]. 
The quantification of filters in coastal environments as well as the role of aging on filter toxicity merits further research. Enhanced public awareness about the toxicity of discarded $\mathrm{CB}$ in marine and coastal areas may help to decrease their environmental hazards. Research concerning the impacts of smoked cigarette filters on marine life is crucial for consolidating a remedial policy [44].

This paper analyses the abundance of CB in different coastal sites in Southern Spain. The most contaminated sites are identified in order to address and better understand CB distribution and abundance according to beach characteristics. Solutions to decrease or eliminate $\mathrm{CB}$ from these sites are proposed.

\section{Materials and Methods}

This paper examines CB items' abundance counted in 188 beach litter assessments carried out by a research group belonging to the University of Cádiz (Spain). The assessments were carried out in different Southern Spanish provinces (Figure 1) such as the mesotidal coast of Cádiz Province and the microtidal coasts of Alacant and Ceuta. Ceuta is located in North Africa, in the Gibraltar Strait area, but administratively belongs to Spain. Data were obtained from March 2018 to April 2019 and general information on the investigated areas and their litter content can be consulted in previously published papers $[15,16,21,45]$.

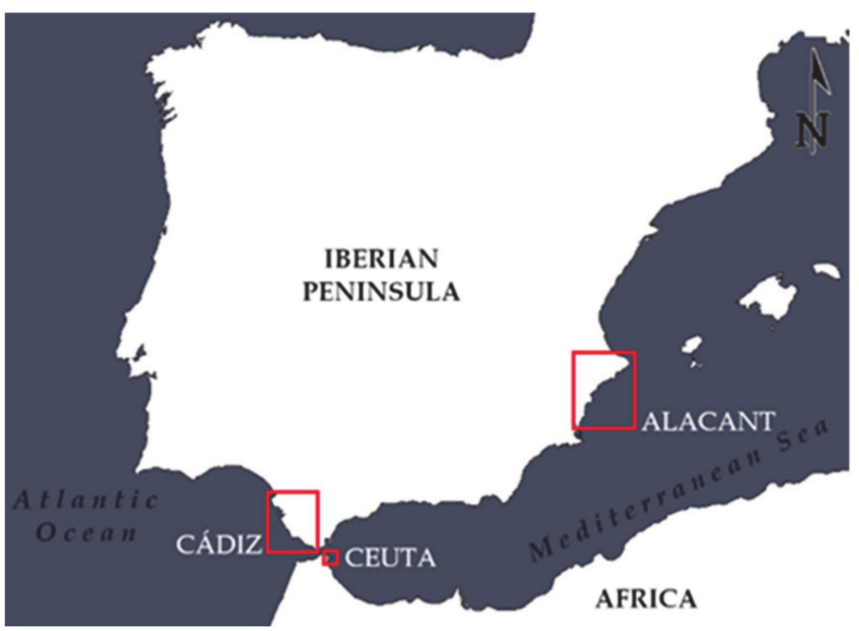

Figure 1. Study area: the provinces of Cádiz, Ceuta and Alacant (Southern Spain).

All coastal sites have been categorized into four of the five beach typologies according to the definitions of Williams and Micallef (2009): Remote, Rural, Village and Urban bathing areas [46]. In addition, the type of beach sediment has been categorized into two groups, i.e., "sand" and "other" (coarser sediments such as gravel, boulder, etc., and rocky shore). Sediment characteristics strongly determine cleaning operations modalities, i.e., mechanical clean-up is usually carried out on sand beaches (e.g., beach cleaners) [47] and manual operations at other beach locations [15].

A beach sector of $100 \mathrm{~m}$ in length has been investigated at each coastal site according to a well-established method widely used during recent decades by the science community [5,48-52]. The assessed width of each beach ranged from the water position at the moment of the survey (usually coinciding with the low tide level) to the landward end of the beach represented by dune toe, a seawall/revetment, etc., and such surface was covered by an observer that moved along $5 \mathrm{~m}$ apart transects parallel to the shoreline. All cigarette butts that were seen with the naked eye were counted, even if they were half-buried.

Box plots were used to represent the number of $C B$, and results in the text were expressed as mean and median values because distributions were skewed towards higher values, i.e., mean value $>$ median value. The mean (or average value) is conventionally a popular estimator of the midpoint in a dataset, but is greatly affected by outliers, i.e., any 
single value of the data set that is extremely high or low compared to the rest. For this reason, in this study, the median value is taken as a better measure of the midpoint.

\section{Results and Discussion}

A total of 29,919 cigarette butts was counted in 188 litter assessments (Table 1) that covered a total length of $18.8 \mathrm{~km}$ of coastline. Mean and median values of $\mathrm{CB}$ abundance per $100 \mathrm{~m}$ of beach length, calculated from all data used in this research, were $159\left(0.038 \mathrm{CB} / \mathrm{m}^{2}\right)$ and $68\left(0.021 \mathrm{CB} / \mathrm{m}^{2}\right)$, respectively, with important differences between beaches.

Table 1. Number of sites according to each research and data of cigarette butts (CB).

\begin{tabular}{|c|c|c|c|c|c|}
\hline No. & Date & Province & Sites $^{1}$ & $\begin{array}{l}\text { Mean/Median } \\
\text { Values }\end{array}$ & $\begin{array}{l}\text { Mean/Median Density } \\
\text { Values }\left(\mathrm{CB} / \mathrm{m}^{2}\right)\end{array}$ \\
\hline 1 & March-April 2018 & Alacant & 56 & $82 / 40.5$ & $0.023 / 0.013$ \\
\hline 2 & August 2018 & Alacant & 56 & $229 / 121$ & $0.061 / 0.041$ \\
\hline 3 & October 2018 & Cádiz & 40 & $271 / 90$ & $0.040 / 0.013$ \\
\hline 4 & February 2019 & Ceuta & 12 & $18.5 / 6$ & $0.008 / 0.002$ \\
\hline 5 & March 2019 & Ceuta & 12 & $44 / 27$ & $0.023 / 0.020$ \\
\hline 6 & April 2019 & Ceuta & 12 & $73 / 76.5$ & $0.040 / 0.038$ \\
\hline
\end{tabular}

${ }^{1}$ The number of sites assessed was chosen according to the kilometres of coast length investigated in each province.

Outliers were identified and corresponded with sites showing a great number of CB. Different factors affect CB abundance on beaches, such as seasonality (which determines the number of visitors), beach typology, type of sediment, and beach accessibility $[12,14,15,53-56]$. These factors are investigated in detail in following sections.

\subsection{Seasonality}

The presence of $\mathrm{CB}$ varied considerably from beach to beach according to the season in which the survey was carried out (Table 1, Figure 2a). Assessments carried out in the summer or shortly after, e.g., surveys at Alacant and Cádiz beaches $[15,16]$, were generally the ones that recorded the highest number of CB. In Alacant, a mean value of 229 items per $100 \mathrm{~m}$ unit of beach length (median $=121$ ) was observed, and in the case of Cádiz, CB abundance reached a mean value of 271 items (median $=90$ ).

(a)

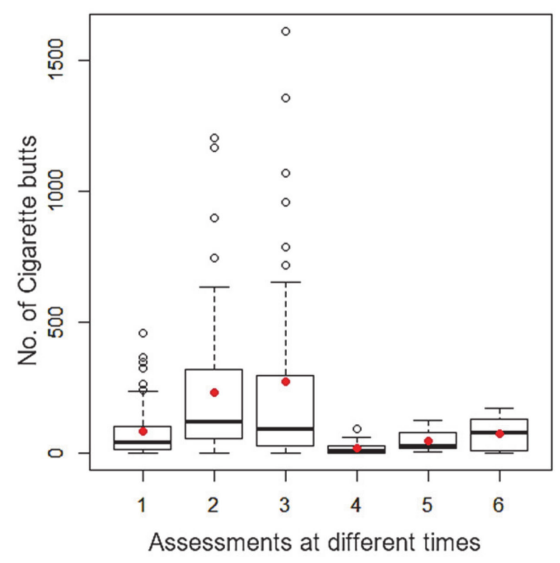

(b)

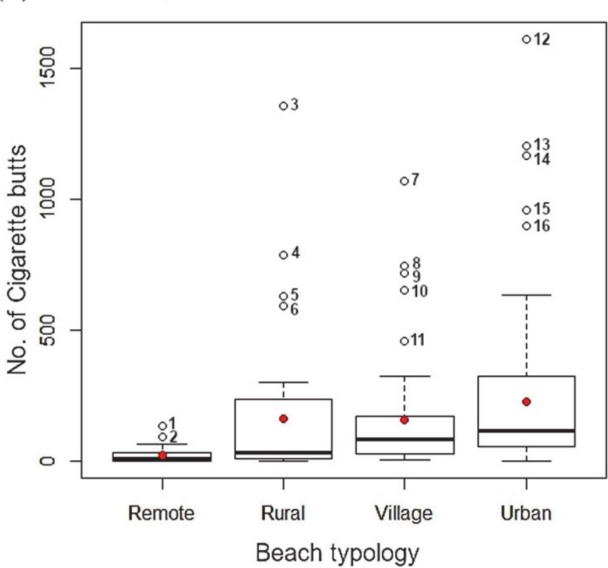

(c)

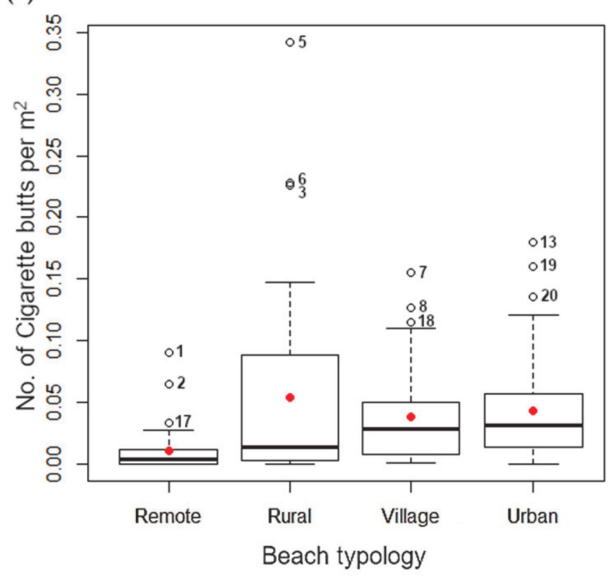

Figure 2. (a) Box plots of cigarette butts (CB) abundance according to different seasons: 1-Alacant-March/April 2018. 2-Alacant-August 2018. 3-Cádiz-October 2018. 4-Ceuta-February 2019. 5-Ceuta-March 2019. 6-Ceuta-April 2019; (b) Box plots of $\mathrm{CB}$ per beach typology; (c) Box plots of $\mathrm{CB} / \mathrm{m}^{2}$ per beach typology. Boxes enclose $50 \%$ of data, associated standard deviations are represented with whiskers, averages with red dots, and median values with black lines. Outliers were marked from no. 1 to no. 20 (see Table 2 for more information). 
Table 2. Beaches that contained an unusual number of cigarette butts (CB) according to beach typology.

\begin{tabular}{cccccccc}
\hline No. ${ }^{1}$ & Beach Name & Typology & Province & Sediment & Date & No. of CB & No. of CB/m ${ }^{2}$ \\
\hline 1 & El Desnarigado & Remote & Ceuta & Other & April 2019 & 135 & 0.090 \\
2 & Cala d'Ambolo & Remote & Alacant & Other & August 2018 & 90 & 0.065 \\
\hline 3 & Cala del Aceite & Rural & Cádiz & Sand & October 2018 & 1358 & 0.226 \\
4 & Camposoto & Rural & Cádiz & Sand & October 2018 & 786 & 0.088 \\
5 & Agua Amarga & Rural & Alacant & Other & August 2018 & 631 & 0.342 \\
6 & Cala del Moraig & Rural & Alacant & Other & August 2018 & 594 & 0.228 \\
\hline 7 & La Barrosa & Village & Cádiz & Sand & October 2018 & 1069 & 0.155 \\
8 & Tabarca & Village & Alacant & Other & August 2018 & 744 & 0.127 \\
9 & La Ballena & Village & Cádiz & Sand & October 2018 & 718 & 0.110 \\
10 & Bajo de Guía & Village & Cádiz & Sand & October 2018 & 653 & 456 \\
11 & Tabarca & Village & Alacant & Other & April 2018 & 456 \\
\hline 12 & Los Bateles & Urban & Cádiz & Sand & October 2018 & 1612 & 0.078 \\
13 & Llevant & Urban & Alacant & Sand & August 2018 & 1203 & 0.121 \\
14 & L'Arenal & Urban & Alacant & Sand & August 2018 & 1166 & 0.180 \\
15 & Sta. María del Mar & Urban & Cádiz & Sand & October 2018 & 958 & 0.103 \\
16 & Cala Finestrat & Urban & Alacant & Sand & August 2018 & 896 & 0.115 \\
\hline 17 & Els Tossals & Remote & Alacant & Sand & August 2018 & 60 & 0.092 \\
\hline 18 & Río San Pedro & Village & Cádiz & Sand & October 2018 & 323 & 0.033 \\
\hline 19 & Playa del Cura & Urban & Alacant & Sand & August 2018 & 632 & 0.115 \\
20 & Arenales del Sol & Urban & Alacant & Sand & August 2018 & 400 \\
\hline
\end{tabular}

${ }^{1}$ The numbering of these beaches corresponds tothe outliers showed in Figure $2 b, c$.

This was mainly due to the high number of national and international tourists that visit the beach and coastal villages and cities in Spain during summer holidays (Figure 3). The huge accumulation of $\mathrm{CB}$ during summer months takes place despite the increased efforts by municipalities in beach cleaning operations. This suggests that present waste management plans must be improved and that educational initiatives and penalties are needed to enhance beachgoer's responsibility. Whoever pollutes should pay or carry out community works (e.g., beach clean-ups). During the assessments, it was noted that beachgoers that throw away $\mathrm{CB}$ and other items are both national and international tourists, young and old, men and women, that go to the beach alone or with friends/relatives. Therefore, education is key and the media have a responsibility to promote good behavioural conduct in the population. Anti-pollution campaigns should be implemented every year before the summer period to prevent and hence reduce beach littering.
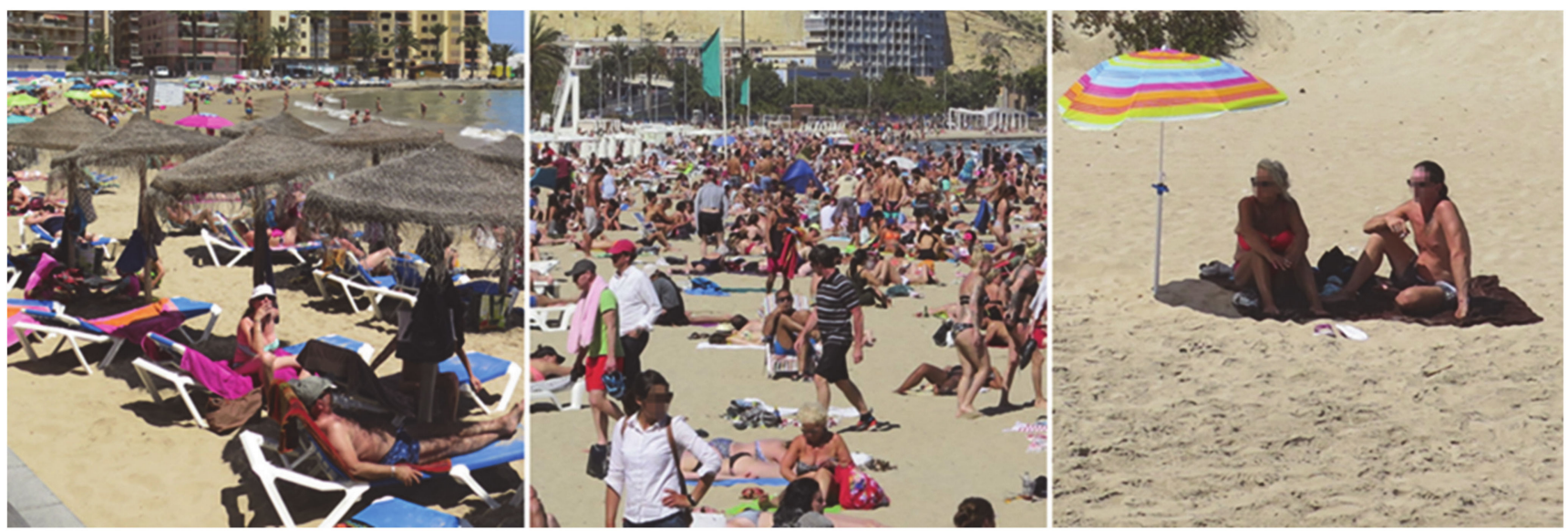

Figure 3. Three Mediterranean urban beaches located in the province of Alacant. In each shot, there are smoking beachgoers. 
In contrast, the assessments that recorded the lowest values of $\mathrm{CB}$ were in February and March and corresponded to the surveys carried out in Ceuta. In April, an increase in CB abundance was observed, both in Alacant and Ceuta (Table 1, Figure 2a). This increase is related to the increased number of beach visitors at the beginning of good weather conditions that determine seasonal peaks of visitors in summer [45]. Visitor numbers is a determining factor in the presence of $\mathrm{CB}$ and other recreational litter items on beaches, as observed by numerous researchers in different places $[11,55,57]$.

\subsection{Beach Typology}

An interesting factor to take into consideration in littering studies is beach typology, which deals with beach background environment and greatly determines the number and type of beach users. Median values of CB numbers increased linearly according to beach typology, from Remote beaches (9 items), Rural (31) and Village (83) to Urban (114 items, see black lines in Figure 2b). Figure 2c shows the same trend, expressed as $C B / \mathrm{m}^{2}$ in $100 \mathrm{~m}$ beach length. However, if data are only expressed as $C B$ numbers per $\mathrm{m}^{2}$, the real number of $\mathrm{CB}$ on a beach can be underestimated (see Appendix A for more detailed information). Outliers should not be ignored and taken into consideration to improve sound management measures. Beaches that were considered as an outlier within each typology are shown in Table 2.

\subsubsection{Remote}

A total of 32 assessments were carried out on remote beaches and 10 assessments did not record any CB items. Overall, a total number of $684 \mathrm{CB}$ items were counted. Therefore, remote beaches contained the lowest number of $C B$ (mean $=21$; median $=9$; Table 3, Figure $2 b$ ) - this being the combination of different variables that are difficult to quantify.

Table 3. Number of assessments, mean and median CB values per beach typology.

\begin{tabular}{cccccc}
\hline Typology & Assessments & $\begin{array}{c}\text { Mean/Median } \\
\text { Values }\end{array}$ & Range of Values & Total & $\begin{array}{c}\text { Mean/Median } \\
\text { Values }\left(\mathbf{m}^{2} \mathbf{)}\right.\end{array}$ \\
\hline Remote & 32 & $21 / 9.5$ & $0-135$ & 684 & $0.010 / 0.003$ \\
Rural & 37 & $162 / 31$ & $0-1358$ & 5994 & $0.053 / 0.013$ \\
Village & 53 & $155 / 83$ & $3-1069$ & 8206 & $0.038 / 0.028$ \\
Urban & 66 & $228 / 114$ & $0-1612$ & 15,035 & $0.043 / 0.031$ \\
\hline
\end{tabular}

On one hand, such results are linked to the level of beach management, which is the lowest compared to other beach typologies since litter bins and clean-up operations are usually not observed/implemented in such beaches [58,59]. On the other hand, the number of visitors to these beaches is quite low due to the difficulty of access (mainly by boat or on foot-a walk of $300 \mathrm{~m}$ or more is needed), and the fact that they are not supported by public transport [46]. Hence, the total amount of litter discarded by the limited number of visitors on remote beaches is very small. Very similar circumstances occur in other countries, for example, generally, no $\mathrm{CB}$ were observed in remote beaches located on the Baltic Sea [56]. Another example of remote beaches without CB items are those along the Moroccan Mediterranean coast [60]. In order to improve beach quality, and considering that major litter quantities on remote and inaccessible beaches may be linked to marinebased sources and less frequent clean ups [61], remote beaches must not be ignored by coastal managers that have to implement sound management actions. In this paper, on the Desnarigado beach (no. 1, Ceuta, Table 2), 135 CB items were counted in April-during this month, the beach recorded a greater influx of visitors than previous months. It is also one of the smallest and most popular beaches investigated in this paper. The high number of CB recorded in Ambolo Beach-90 CB items (no. 2, Alacant, Table 2)—is linked to the fact that it is a very narrow pocket of beach of only $100 \mathrm{~m}$ in length, which is overcrowded in the summer months due to its scenic beauty [59], despite the risk of landslides (Figure 4a). 

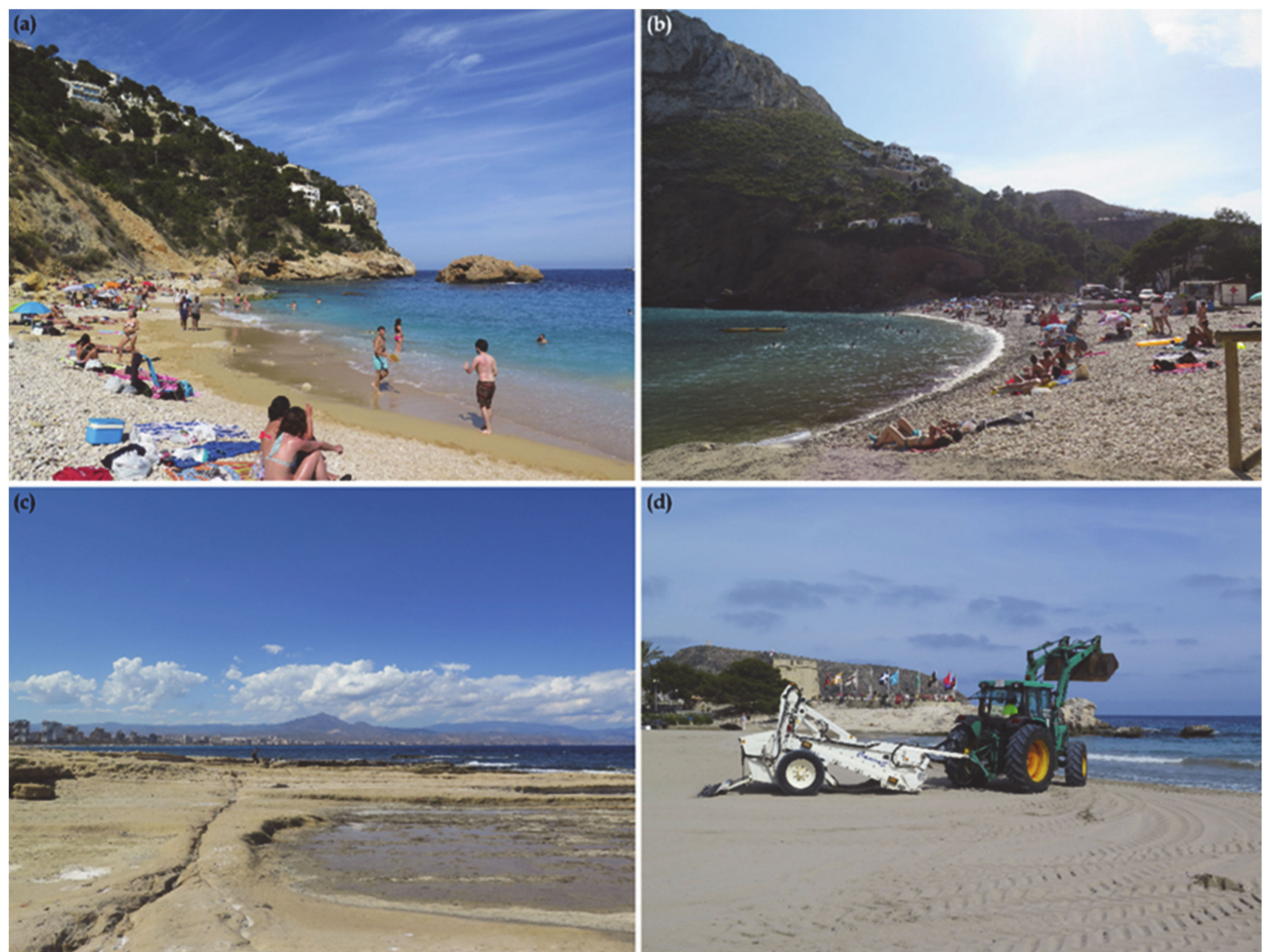

Figure 4. Mediterranean coastal sites at Alacant Province: (a) Ambolo, remote beach; (b) Granadella, rural beach; (c) Cap de l'Horta, remote beach; (d) beach cleaner in "l'Ampolla", village beach.

\subsubsection{Rural}

A total of 37 assessments were carried out on rural beaches and no CB items were recorded in 5 assessments. Overall, a total number of 5994 CB items were counted (Table 3). Rural beaches do not usually have as many visitors as village or urban beaches but there are some exceptions, particularly in the Mediterranean where they are accessible from numerous roads that run parallel to the coastline (Figure $4 \mathrm{~b}$ ). Further, due to their physical characteristics and location, rural beaches are associated with lower management efforts than more urbanised beaches. They are also greatly valued by visitors for their natural qualities [46] and some of them can receive as many visits as the more urbanised beaches do. This is reflected in the mean values of $C B$ recorded along the investigated coasts (Figure $2 b$ ): rural beaches outnumbered village beaches (see the red dots in Figure $2 b$ ) because they recorded more dispersed data and presented some outliers, i.e., rural beaches with a great number of $C B$ (mean $=162$; median $=31$, Table 3 , Figure $2 \mathrm{~b}$ ). The atypical values in rural beaches (no. 3-6, Table 2) were linked to the large number of visitors during summer, the easy accessibility for beachgoers observed in most of them and the difficulty of carrying out cleaning operations with mechanical tools. Cleaning operations are difficult due to the impossibility of access for beach cleaners and, at places, type of substrate composition such as boulders, cobbles and rocky shores (e.g., Granadella beach with boulders and some beaches of "Cap de l'Horta" with a rocky shore, Figure 4b,c). 


\subsubsection{Village}

A total of 53 assessments were carried out on village beaches and 8206 CB items were counted in total. All the beaches of this typology were found to have CB items $($ mean $=155$; median $=83$, Table 3, Figure $2 b)$. Village beaches are located outside the main urban environment and related to a small but permanent population compared to urban beaches [46]. In these beaches, the number of $C B$ was less dispersed than on rural beaches (Figure 2 b) due to management actions being generally well established by local municipalities for village beaches. The highest recorded values were due to various specific circumstances. Firstly, in the Cádiz coast, beaches such as "La Barrosa" and "La Ballena" (no. 7 and 9, Table 2) received as many visitors as urban beaches during the summer months. In addition, they belong to a mesotidal environment (tidal range between 2 and $4 \mathrm{~m}$ ), which favours the accumulation of the smallest and lightest items such as CB in specific beach zones, e.g., the high tide line. In the case of Bajo de Guía beach (no. 10, Cádiz, Table 2), the high number of $\mathrm{CB}$ was mainly due to the fact that it is located at the mouth of the Guadalquivir River and rivers are an important source of beach litter [62,63]. Additionally, this last beach, together with CB items, recorded a high quantity of fishing debris [16], making it one of the most contaminated in the Cádiz Province. Secondly, assessments on village beaches that recorded massive $\mathrm{CB}$ abundance in Alacant were carried out on Tabarca beach (no. 8 and 11, Table 2), which is surrounded by one of the most important and oldest marine reserves in Spain [64], which records thousands of visitors in the summer months [65].

\subsubsection{Urban}

Urban beaches (Figure 3) recorded the greatest number and dispersion in the number of $\mathrm{CB}$, as observed by comparing the mean and median values with those recorded in other beach typologies (Figure 2b). A total of 66 assessments were carried out on urban beaches and 15,035 CB were counted (mean $=228$; median $=114$, Table 3, Figure 2b). No CB items were observed on the San Amaro beach (Ceuta) in February, one of the months that registered the lowest temperatures and fewest beach visitors. The highest numbers of CB items (no. 12-16, Table 2) were due to the high number of beach users at these sites, and were also related to great beach dimensions that required more transects in their assessment. Therefore, as the number of transects increased during the assessment, the chance of finding more CB also increased. The increase in CB and other litter items in urban beaches was also observed at different sites such as on the Baltic Sea coast [56], Morocco [66] and Senegal [67].

\subsection{Accessibility}

Accessibility is an interesting factor that has to be taken into account because it strongly determines the number of users. An attempt has been made in this paper to compare $C B$ assessments made on beaches close to a car park (less than $200 \mathrm{~m}$ ), at a medium distance (200-300 m), and at beaches where parking was more than $300 \mathrm{~m}$ away. Unfortunately, the massive level of construction recorded close to the coast has left us with a desolate scene that made this comparison difficult: $79 \%$ of the assessments were carried out on beaches with a car park close, $5 \%$ were carried out in beaches located at a medium distance and, finally, the other $16 \%$ were in locations far from a car park. In spite of this, the trend is as expected: the further away the beach was from the car park, the fewer CB items were counted. The mean and median values for each case were 186 and 90 items, respectively, for beaches close to a parking area, 80 and 59 for medium cases and, finally, 55 and 8 for beaches far away from parking areas. This confirmed that lowest $C B$ values were observed at beaches at a distance of more than $300 \mathrm{~m}$ from the parking area. On the contrary, beaches with a great abundance of $\mathrm{CB}$ were quite accessible and located near to a car park. In the Black Sea coast, tourism-related recreational litter showed an increase in the summer months, with accessibility being an important factor [55]. The accessibility of the shores, 
particularly for vehicles (e.g., in riverine environments), also influenced the degree of littering [62].

\subsection{Beach Sedimentology}

The type of sediment is an important factor since it strongly determines the type of cleaning operation [47]. Assessments carried out on sandy beaches $(n=108)$ presented mean and median CB items values of 211 and 91, respectively. Assessments on other beaches $(n=80)$ showed mean and median values of 89 and 27, respectively. Along the investigated areas, mechanical cleaning is carried out on practically all urban sand beaches (Figure $4 \mathrm{~d}$ ) since it is easy for administrations because few workers and efforts are needed compared to manual operations. However, in some places, because of the great amount of litter, the implementation of more effective and expensive techniques is sometimes required [68]. However, the use of heavy equipment is also less respectful of the coastal environment because it damages small dunes, vegetation, and even bird and turtle species that nest at the coast $[6,69,70]$. Mechanic operations (Figure 4d) also contribute to erosion and change the physical characteristics of the beach [71]. Moreover, this type of cleaning does not collect all the litter, as it leaves behind small-sized items such as plastic fragments, cotton bud sticks, bottle caps and CB $[6,17,60,72,73]$ that are more efficiently recollected by manual clean-up operations $[60,73]$. The results also indicate that considering each beach typology, sandy beaches contain more CB items, which are frequently buried or semiburied in the sand [14,74]. In cobble beaches, the burial of (essentially) small items was also observed [75]. Last, despite the implementation and efficiency of cleaning operations, it must be highlighted that beach users greatly value sandy beaches, much more than gravel or pebble ones [76,77], so the former receive huge numbers of visitors and, in consequence, more $\mathrm{CB}$ items are present on them.

\subsection{Cigarette Butt Distribution in Beach Environment}

Cigarette butts and many other items are not distributed in a homogeneous way along the cross-shore beach profile $[16,75,78,79]$. On the Mediterranean beaches assessed in this paper, i.e., at Alacant and Ceuta, most CB items were found on the dry beach and many of them were accumulated near the landward limit of the beach $[15,16]$. On the Atlantic beaches such as those of Cádiz, most CB items were counted in correspondence of the high tide water level due to the effect of the flooding tide that moves whatever is located in the foreshore and on the dry beach inland, where the users spend most of their time [16]. At mesotidal places, most CB items ( $73.6 \%$ of the total amount) were found at the high tide water level and, secondly, on the backshore (22\%). In the foreshore zone, CB items were less abundant: foreshore recorded $4.1 \%$ of the total amount, while at the low tide water level, only $0.3 \%$ was recorded [16]. Such information regarding CB distribution according to tidal conditions and/or the presence of human structures in the backshore are very useful to plan adequate clean-up operations.

\section{Conclusions}

Each beach is unique and their management is the responsibility of local municipalities and administrations. It is advisable to manage each beach in the most appropriate way, taking into consideration the determinant factors (e.g., tourism seasonality, beach typology, accessibility, type of sediment, etc.) that most influence the abundance of beach litter. Almost all studies conducted on beach litter have shown that the dominant material is plastic, with CB often being the most common item. In addition, their abundance is often underestimated because $\mathrm{CB}$ are often buried in coastal sediments or rapidly washed away by waves and currents. According to this, beach clean-ups should be carried out with special attention at the beach landward limit (usually coinciding with a seawall, a promenade, dunes, etc.) on both tidal and micro-tidal beaches. On tidal coasts (e.g., the Cádiz coast), special attention should be devoted to the high tide line. Proper cleaning operations according to the characteristics of a beach are essential to reduce the number 
of $\mathrm{CB}$ items, but are not enough to solve the problem. Authorities have to emphasise anti-pollution campaigns to educate the general public and, particularly, beachgoers.

Author Contributions: Conceptualization, F.A.-M.. and G.A.; methodology, F.A.-M. and M.T.A.-T.; software, F.A.-M.; validation, M.T.A.-T., M.O.R. and G.A.; formal analysis, M.O.R.; investigation, F.A.-M.; resources, G.A.; data curation, F.A.-M.; writing-original draft preparation, F.A.-M. and M.O.R.; writing-review and editing, M.T.A.-T. and G.A; visualization, G.A.; supervision, M.O.R. and G.A.; funding acquisition, G.A. All authors have read and agreed to the published version of the manuscript.

Funding: This research was funded by Andalusia PAI Research Group RNM-328.

Institutional Review Board Statement: Not applicable.

Informed Consent Statement: Not applicable.

Acknowledgments: This research is a contribution to the RED PROPLAYAS network and to Andalusia PAI Research Group RNM-328. Special thanks to all those people who remove litter from beaches voluntarily and also those that do not contribute to dump it.

Conflicts of Interest: The authors declare no conflict of interest.

\section{Appendix A}

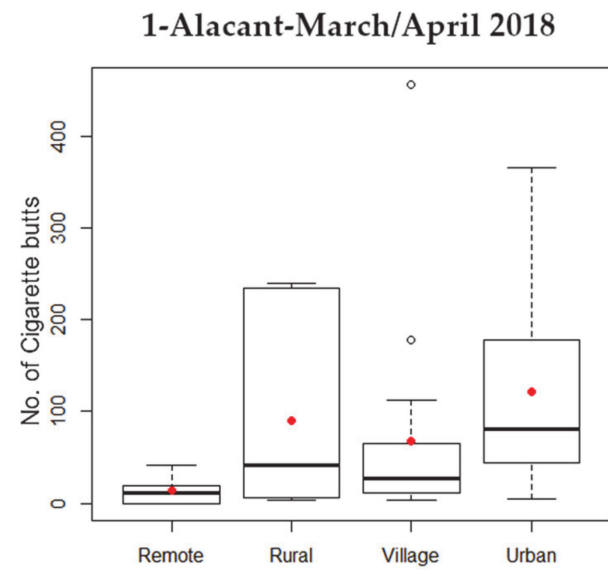

4-Ceuta-February 2019

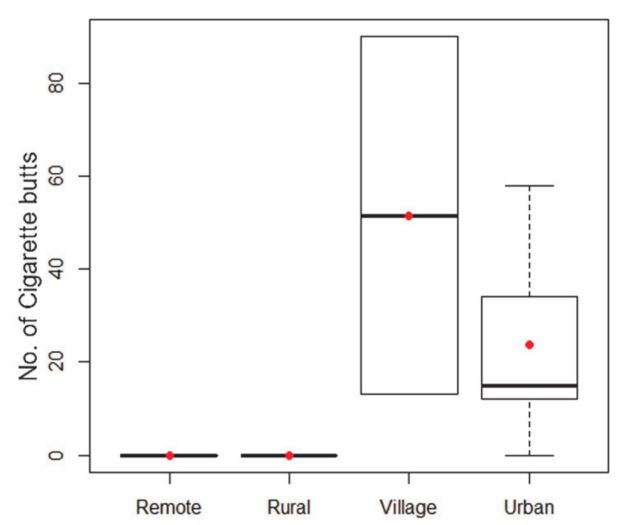

2-Alacant-August 2018

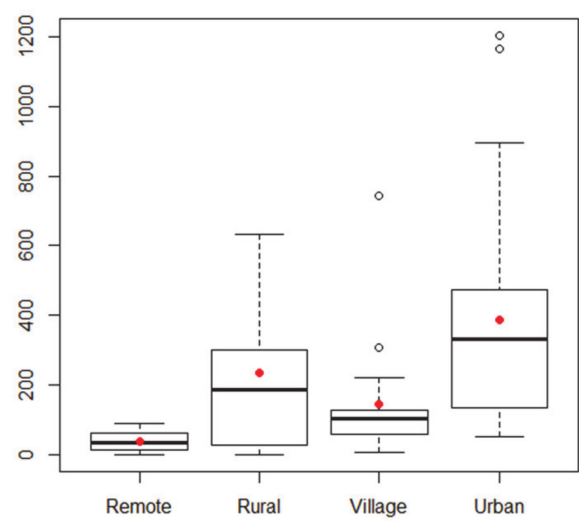

5-Ceuta-March 2019

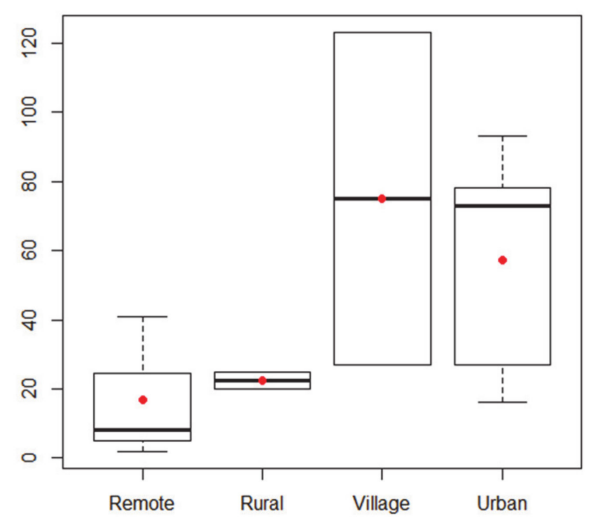

3-Cádiz-October 2018

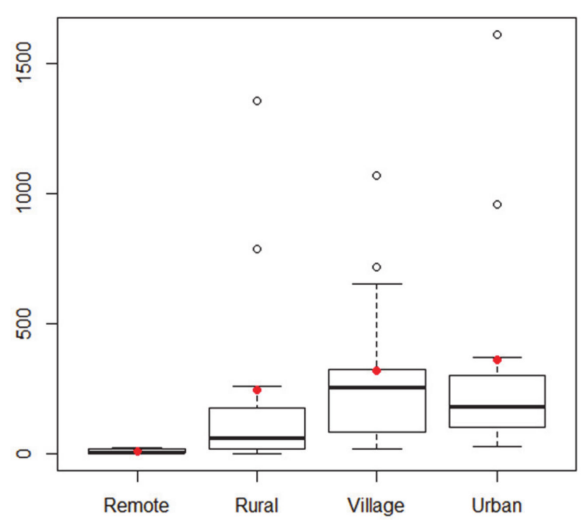

6-Ceuta-April 2019

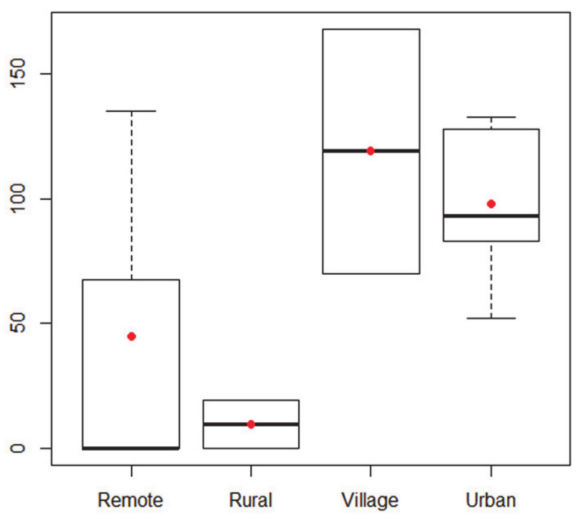

Figure A1. Box plots of total number of cigarette butts per beach typology in each one of the six surveys. 


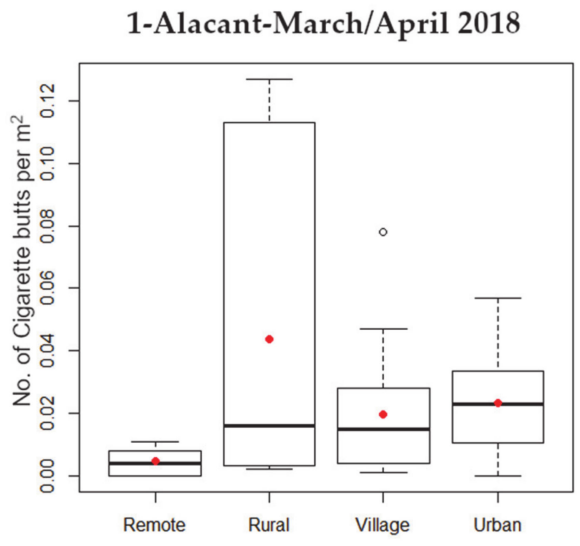

4-Ceuta-February 2019

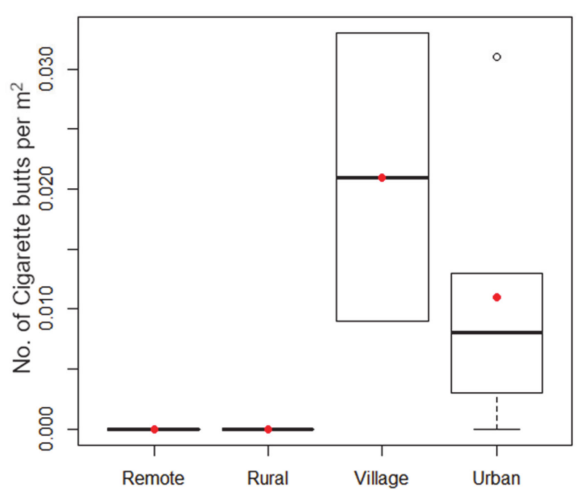

2-Alacant-August 2018

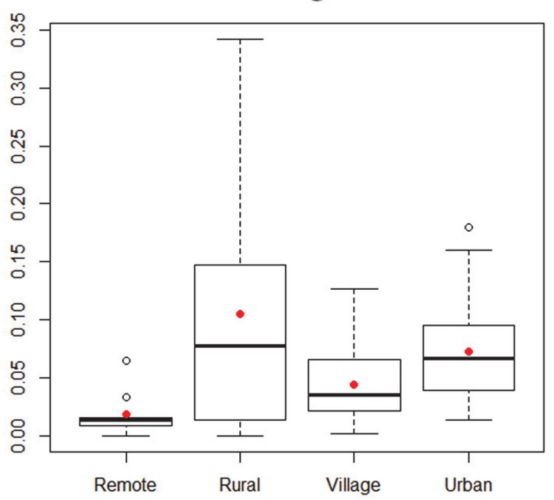

5-Ceuta-March 2019

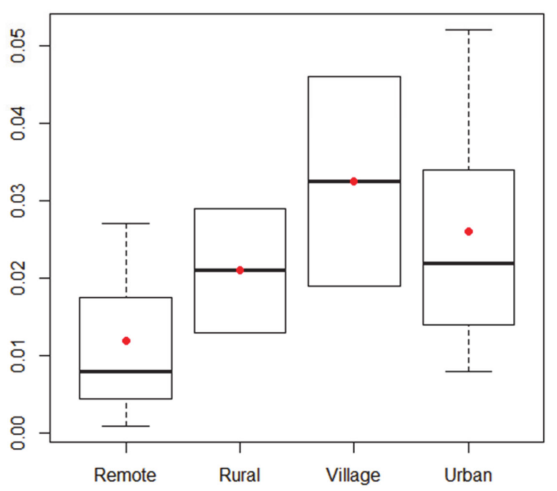

3-Cádiz-October 2018

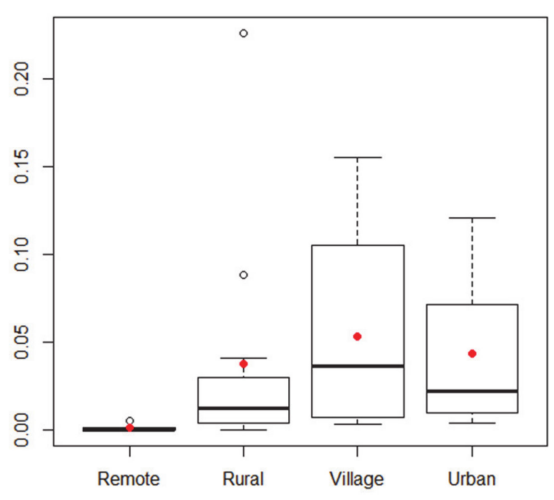

6-Ceuta-April 2019

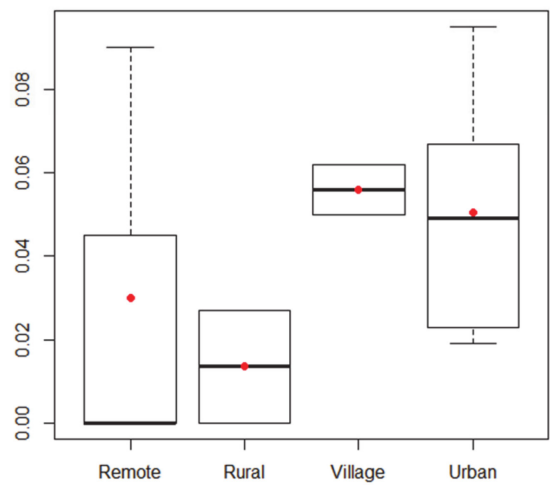

Figure A2. Box plots of cigarette butts density $\left(\mathrm{CB} / \mathrm{m}^{2}\right)$ per beach typology in each one of the six surveys.

\section{References}

1. Aguilar, R.; Marín, P.; Álvarez, H.; Blanco, J.; Sánchez, N. Plastic in the Deep: An Invisible Problem. How the Seafloor Becomes a Plastic trap; Oceana: Washington, DC, USA, 2020; p. 24.

2. Chiba, S.; Saito, H.; Fletcher, R.; Yogi, T.; Kayo, M.; Miyagi, S.; Ogido, M.; Fujikura, K. Human footprint in the abyss: 30 year records of deep-sea plastic debris. Mar. Policy 2018, 96, 204-212. [CrossRef]

3. Convey, P.; Barnes, D.K.; Morton, A. Debris accumulation on oceanic island shores of the Scotia Arc, Antarctica. Polar Biol. 2002, 25, 612-617. [CrossRef]

4. Anfuso, G.; Bolívar-Anillo, H.J.; Asensio-Montesinos, F.; Manzolli, R.P.; Portz, L.; Daza, D.A.V. Beach litter distribution in Admiralty Bay, King George Island, Antarctica. Mar. Pollut. Bull. 2020, 160, 111657. [CrossRef] [PubMed]

5. UNEP. Marine Litter: A Global Challenge; UNEP: Nairobi, Kenya, 2009; p. 232.

6. Ariza, E.; Leatherman, S.P. No-Smoking Policies and Their Outcomes on U.S. Beaches. J. Coast. Res. 2012, 278, 143-147. [CrossRef]

7. Cole, M.; Lindeque, P.; Halsband, C.; Galloway, T.S. Microplastics as contaminants in the marine environment: A review. Mar. Pollut. Bull. 2011, 62, 2588-2597. [CrossRef] [PubMed]

8. Ocean Conservancy. Trash Travels: From Our Hands to the Sea, Around the Globe and Through Time. 2010 Report, 60p. Available online: https:/ / oceanconservancy.org/wp-content/uploads/2017/04/2010-Ocean-Conservancy-ICC-Report.pdf (accessed on 13 October 2020).

9. Kungskulniti, N.; Charoenca, N.; Hamann, S.; Pitayarangsarit, S.; Mock, J. Cigarette Waste in Popular Beaches in Thailand: High Densities that Demand Environmental Action. Int. J. Environ. Res. Public Health 2018, 15, 630. [CrossRef] [PubMed]

10. Loizidou, X.I.; Loizides, M.I.; Orthodoxou, D. Persistent marine litter: Small plastics and cigarette butts remain on beaches after organized beach cleanups. Environ. Monit. Assess. 2018, 190, 414. [CrossRef]

11. Araújo, M.C.B.; Costa, M.F. A critical review of the issue of cigarette butt pollution in coastal environments. Environ. Res. 2019, 172, 137-149. [CrossRef] [PubMed]

12. Simeonova, A.; Chuturkova, R. Marine litter accumulation along the Bulgarian Black Sea coast: Categories and predominance. Waste Manag. 2019, 84, 182-193. [CrossRef]

13. Rangel-Buitrago, N.; Barría-Herrera, J.; Vergara-Cortés, H.; Contreras-López, M.; Agredano, R. A snapshot of the litter problem along the Viña del Mar-Concón coastal strip, Valparaíso region. Chile. Mar. Pollut. Bull. 2020, 160, 111524. [CrossRef]

14. Martinez-Ribes, L.; Basterretxea, G.; Palmer, M.; Tintoré, J. Origin and abundance of beach debris in the Balearic Islands. Sci. Mar. 2007, 71, 305-314. [CrossRef] 
15. Asensio-Montesinos, F.; Anfuso, G.; Randerson, P.; Williams, A. Seasonal comparison of beach litter on Mediterranean coastal sites (Alicante, SE Spain). Ocean. Coast. Manag. 2019, 181, 104914. [CrossRef]

16. Asensio-Montesinos, F.; Anfuso, G.; Ramírez, M.O.; Smolka, R.; Sanabria, J.G.; Enríquez, A.F.; Arenas, P.; Bedoya, A.M. Beach litter composition and distribution on the Atlantic coast of Cádiz (SW Spain). Reg. Stud. Mar. Sci. 2020, 34, 101050. [CrossRef]

17. Ariza, E.; Jiménez, J.A.; Sardá, R. Seasonal evolution of beach waste and litter during the bathing season on the Catalan coast. Waste Manag. 2008, 28, 2604-2613. [CrossRef] [PubMed]

18. Balčiūnas, A.; Blažauskas, N. Scale, origin and spatial distribution of marine litter pollution in the Lithuanian coastal zone of the Baltic Sea. Baltica 2014, 27, 39-44. [CrossRef]

19. Schernewski, G.; Balciunas, A.; Gräwe, D.; Gräwe, U.; Klesse, K.; Schulz, M.; Wesnigk, S.; Fleet, D.; Haseler, M.; Möllman, N.; et al. Beach macro-litter monitoring on southern Baltic beaches: Results, experiences and recommendations. J. Coast. Conserv. 2018, 22, 5-25. [CrossRef]

20. Krelling, A.P.; Williams, A.T.; Turra, A. Differences in perception and reaction of tourist groups to beach marine debris that can influence a loss of tourism revenue in coastal areas. Mar. Policy 2017, 85, 87-99. [CrossRef]

21. Asensio-Montesinos, F.; Ramírez, M.O.; González-Leal, J.M.; Carrizo, L.; Anfuso, G. Characterization of plastic beach litter by Raman spectroscopy in South-western Spain. Sci. Total Environ. 2020, 744, 140890. [CrossRef]

22. Slaughter, E.; Gersberg, R.M.; Watanabe, K.; Rudolph, J.; Stransky, C.; Novotny, T.E. Toxicity of cigarette butts, and their chemical components, to marine and freshwater fish. Tob. Control. 2011, 20, i25-i29. [CrossRef]

23. Moriwaki, H.; Kitajima, S.; Katahira, K. Waste on the roadside, 'poi-sute' waste: Its distribution and elution potential of pollutants into environment. Waste Manag. 2009, 29, 1192-1197. [CrossRef]

24. Novotny, T.E.; Lum, K.; Smith, E.; Wang, V.; Barnes, R. Filtered cigarettes and the case for an environmental policy on cigarette waste. Int. J. Environ. Res. Public Health 2009, 6, 1691-1705. [CrossRef] [PubMed]

25. Caridi, F.; Sabbatini, A.; Birarda, G.; Costanzi, E.; De Giudici, G.; Galeazzi, R.; Medas, D.; Mobbili, G.; Ricciutelli, M.; Ruello, M.L.; et al. Cigarette butts, a threat for marine environments: Lessons from benthic foraminifera (Protista). Mar. Environ. Res. 2020, 162, 105150. [CrossRef]

26. Green, D.S.; Kregting, L.; Boots, B. Smoked cigarette butt leachate impacts survival and behaviour of freshwater invertebrates. Environ. Pollut. 2020, 266, 115286. [CrossRef] [PubMed]

27. Savoca, M.S.; Tyson, C.W.; McGill, M.; Slager, C.J. Odours from marine plastic debris induce food search behaviours in a forage fish. Proc. R. Soc. B Biol. Sci. 2017, 284, 20171000. [CrossRef] [PubMed]

28. Micevska, T.; Warne, M.; Pablo, F.; Patra, R. Variation in, and Causes of, Toxicity of Cigarette Butts to a Cladoceran and Microtox. Arch. Environ. Contam. Toxicol. 2006, 50, 205-212. [CrossRef]

29. Dobaradaran, S.; Nabipour, I.; Saeedi, R.; Ostovar, A.; Khorsand, M.; Khajeahmadi, N.; Hayati, R.; Keshtkar, M. Association of metals (Cd, Fe, As, Ni, Cu, Zn and Mn) with cigarette butts in northern part of the Persian Gulf. Tob. Control. 2017, 26, 461-463. [CrossRef]

30. Tso, T.C. Production, Physiology and Biochemistry of Tobacco Plant; IDEALS: Beltsville, MA, USA, $1990 ;$ p. 785.

31. Frank, R.; Braun, H.E.; Suda, P.; Ripley, B.D.; Clegg, B.S.; Beyaert, R.P.; Zilkey, B.F. Pesticide residues and metal contents in flue-cured tobacco and tobacco soils of southern Ontario, Canada 1980-1985. Tob. Sci. 1987, 21, 40-45.

32. Baker, R.R.; Da Silva, J.R.P.; Smith, G. The effect of tobacco ingredients on smoke chemistry. Part I: Flavourings and additives. Food Chem. Toxicol. 2004, 42, 3-37. [CrossRef]

33. Baker, R.R.; Da Silva, J.R.P.; Smith, G. The effect of tobacco ingredients on smoke chemistry. Part II: Casing ingredients. Food Chem. Toxicol. 2004, 42, 39-52. [CrossRef]

34. Iskander, F.Y.; Klein, D.B.; Bauer, T.L. Determination of trace and minor elements in cigarette paper by neutron activation analysis. Tappi J. 1986, 69, 134-135.

35. Kabata-Pendias, A. Trace Elements in Soils and Plants, 4th ed.; CRC Press: Boca Raton, FL, USA, 2011 ; p. 548.

36. Clark, T.J.; Bunch, J.E. Quantitative Determination of Phenols in Mainstream Smoke with Solid-Phase Microextraction-Gas Chromatography—Selected Ion Monitoring Mass Spectrometry. J. Chromatogr. Sci. 1996, 34, 272-275. [CrossRef]

37. Pertschuk, M.; Glantz, S.A.; Slade, J.; Bero, L.; Hanauer, P.; Barnes, D.E. The Cigarette Papers. J. Public Health Policy 1998, 19, 236. [CrossRef]

38. Doull, J.; Frawley, J.P.; George, W. List of Ingredients Added to Tobacco in the manufacture of Cigarettes by Six Major American Cigarette Companies. Tob. J. Int. 1994, 196, 32-39.

39. Novotny, T.E.; Hardin, S.N.; Hovda, L.R.; Novotny, D.J.; McLean, M.K.; Khan, S. Tobacco and cigarette butt consumption in humans and animals. Tob. Control. 2011, 20, i17-i20. [CrossRef] [PubMed]

40. Hulzebos, C.V.; Walhof, C.; De Vries, T.W. Accidental ingestion of cigarettes by children. Ned. Tijdschr. Geneeskd. 1998, 142, 2569-2571. [PubMed]

41. Smolinske, S.; Spoerke, D.; Spiller, S.; Wruk, K.; Kulig, K.; Rumackt, B. Cigarette and Nicotine Chewing Gum Toxicity in Children. Hum. Toxicol. 1988, 7, 27-31. [CrossRef] [PubMed]

42. Salomon, M.E. Nicotine and tobacco preparations. In Goldfrank's Toxicologic Emergencies, 8th ed.; Goldfrank, L.R., Flomenbaum, N.E., Lewin, N.A., Howland, M.A., Hoffman, R.S., Nelson, L.S., Eds.; McGraw-Hill: New York, NY, USA, 2006; pp. 1221-1230. 
43. Stanley, K.; Stabenau, E.; Landry, A. Debris ingestion by sea turtles along the Texas coast. In Proceedings of the Eighth Annual Workshop on Sea Turtle Conservation and Biology, Fort Fisher, NC, USA, 24-26 February 1988; NOAA Technical Memorandum. pp. 119-121.

44. Wright, S.L.; Rowe, D.; Reid, M.J.; Thomas, K.V.; Galloway, T.S. Bioaccumulation and biological effects of cigarette litter in marine worms. Sci. Rep. 2015, 5, 1-10. [CrossRef]

45. Asensio-Montesinos, F.; Anfuso, G.; Williams, A. Beach litter distribution along the western Mediterranean coast of Spain Mar. Pollut. Bull. 2019, 141, 119-126. [CrossRef]

46. Williams, A.T.; Micallef, A. Beach Management. Principles and Practice; Earthscan: London, UK, 2009; p. 480.

47. Taylor, E.; Owens, E.H. Specialized mechanical equipment for shoreline cleanup. Int. Oil Spill Conf. Proc. 1997, 1997, 79-87. [CrossRef]

48. Cheshire, A.; Adler, E. UNEP/IOC Guidelines on Survey and Monitoring of Marine Litter. United Nations Environment Programme/Intergovernmental Oceanographic Commission: Nairobi, Kenya, 2009.

49. OSPAR Commission. Guideline for Monitoring Marine Litter on the Beaches in the OSPAR Maritime Area; OSPAR Commission: London, UK, 2010; p. 84.

50. Opfer, S.; Arthur, C.; Lippiatt, S. NOAA Marine Debris Shoreline Survey Field Guide; NOAA Marine Debris Program; US National Oceanic and Atmospheric Administration Marine Debris Program: Silver Spring, MD, USA, 2012; p. 19.

51. Vlachogianni, T.; Fortibuoni, T.; Ronchi, F.; Zeri, C.; Mazziotti, C.; Tutman, P.; Mandić, M. Marine litter on the beaches of the Adriatic and Ionian Seas: An assessment of their abundance, composition and sources. Mar. Pollut. Bull. 2018, 131, 745-756. [CrossRef]

52. Nachite, D. Photo Guide for Monitoring Marine Litter on the Mediterranean Moroccan Beaches; Coordination Nationale du Pro-gramme National de Surveillance et d'Evaluation de la Pollution de la Méditerranée: Mai, Marocco, 2019; p. 73.

53. Kammler, M.; Schernewski, G. Spatial and temporal analysis of beach tourism using webcam and aerial photographs. Coastline Rep. 2004, 2, 121-128.

54. Taffs, K.H.; Cullen, M.C. The distribution and abundance of beach debris on isolated beaches of northern New South Wales, Australia. Australas. J. Env. Man. 2005, 12, 244-250.

55. Oztekin, A.; Bat, L.; Gokkurt-Baki, O. Beach litter pollution in Sinop Sarikum Lagoon coast of the southern Black Sea. Turk. J. Fish. Aquat Sc. 2019, 20, 197-205.

56. Kataržytė, M.; Balčiūnas, A.; Haseler, M.; Sabaliauskaitė, V.; Lauciūtè, L.; Stepanova, K.; Nazzari, C.; Schernewski, G. Cigarette butts on Baltic Sea beaches: Monitoring, pollution and mitigation measures. Mar. Pollut. Bull. 2020, 156, 111248. [CrossRef] [PubMed]

57. Simeonova, A.; Chuturkova, R.; Yaneva, V. Seasonal dynamics of marine litter along the Bulgarian Black Sea coast. Mar. Pollut. Bull. 2017, 119, 110-118. [CrossRef] [PubMed]

58. Mooser, A.; Anfuso, G.; Mestanza-Ramón, C.; Williams, A.T. Management Implications for the Most Attractive Scenic Sites along the Andalusia Coast (SW Spain). Sustainability 2018, 10, 1328. [CrossRef]

59. Asensio-Montesinos, F.; Anfuso, G.; Corbí, H. Coastal scenery and litter impacts at Alicante (SE Spain): Management issues. J. Coast. Conserv. 2018, 23, 185-201. [CrossRef]

60. Maziane, F.; Nachite, D.; Anfuso, G. Artificial polymer materials debris characteristics along the Moroccan Mediterranean coast. Mar. Pollut. Bull. 2018, 128, 1-7. [CrossRef]

61. Schmuck, A.M.; Lavers, J.L.; Stuckenbrock, S.; Sharp, P.B.; Bond, A.L. Geophysical features influence the accumulation of beach debris on Caribbean islands. Mar. Pollut. Bull. 2017, 121, 45-51. [CrossRef]

62. Williams, A.T.; Simmons, S.L. Sources of Riverine Litter: The River Taff, South Wales, UK. Water Air Soil Pollut. 1999, 112, 197-216. [CrossRef]

63. Rech, S.; Macaya-Caquilpán, V.; Pantoja, J.; Rivadeneira, M.M.; Madariaga, D.J.; Thiel, M. Rivers as a source of marine litter-A study from the SE Pacific. Mar. Pollut. Bull. 2014, 82, 66-75. [CrossRef] [PubMed]

64. Ramos-Esplá, A.; McNeill, S.E. The status of marine conservation in Spain. Ocean. Coast. Manag. 1994, 24, 125-138. [CrossRef]

65. Ramos-Esplá, A.A. La Reserva Marina de la Isla de Tabarca, una realidad después de un sueño. Canelobre 2012, 60, $284-297$.

66. Nachite, D.; Maziane, F.; Anfuso, G.; Williams, A.T. Spatial and temporal variations of litter at the Mediterranean beaches of Morocco mainly due to beach users. Ocean. Coast. Manag. 2019, 179, 104846. [CrossRef]

67. Tavares, D.C.; Moura, J.F.; Ceesay, A.; Merico, A. Density and composition of surface and buried plastic debris in beaches of Senegal. Sci. Total Environ. 2020, 737, 139633. [CrossRef]

68. Zielinski, S.; Botero, C.M.; Yanes, A. To clean or not to clean? A critical review of beach cleaning methods and impacts. Mar. Pollut. Bull. 2019, 139, 390-401. [CrossRef]

69. La Marina Plaza. Costas Destruye una Duna en l’Estanyó de Dénia Donde Anidaba una Especie Protegida Durante su Enésima Regeneración. Available online: https:/ /lamarinaplaza.com/2018/06/13/costas-destruye-una-duna-en-lestanyo-de-deniadonde-anidaba-una-especie-protegida-durante-su-enesima-regeneracion/ (accessed on 19 November 2020).

70. Econoticias. Deterioro de las dunas de Guadarranque de San Roque (Cádiz). Available online: https:/ / www.ecoticias.com/ medio-ambiente/204390/Deterioro-dunas-Guadarranque-San-Roque-Cadiz (accessed on 19 November 2020).

71. Nordstrom, K.F. Beaches and dunes of human-altered coasts. Prog. Phys. Geogr. Earth Environ. 1994, 18, 497-516. [CrossRef] 
72. Williams, A.T. Definitions and typologies of coastal tourism destinations. In Disappearing Destinations: Climate change and Future Challenges for Coastal Tourism; Jones, A., Phillips, M., Eds.; CABI: Oxfordshire, UK, 2011; pp. 47-66.

73. Williams, A.T.; Randerson, P.F.; Di Giacomo, C.; Anfuso, G.; Macias, A.; Perales, J.A. Distribution of beach litter along the coastline of Cádiz, Spain. Mar. Pollut. Bull. 2016, 107, 77-87. [CrossRef]

74. Araújo, M.C.B.; Costa, M.F. From Plant to Waste: The Long and Diverse Impact Chain Caused by Tobacco Smoking. Int. J. Environ. Res. Public Health. 2019, 16, 2690.

75. Williams, A.T.; Tudor, D. Litter Burial and Exhumation: Spatial and Temporal Distribution on a Cobble Pocket Beach. Mar. Pollut. Bull. 2001, 42, 1031-1039. [CrossRef]

76. Ergin, A.; Karaesmen, E.; Micallef, A.; Williams, A.T. A new methodology for evaluating coastal scenery: Fuzzy logic systems. Area 2004, 36, 367-386. [CrossRef]

77. Ergin, A.; Williams, A.T.; Micallef, A. Coastal Scenery: Appreciation and Evaluation. J. Coast. Res. 2006, 224, 958-964. [CrossRef]

78. Costa, M.F.; Sul, J.A.I.D.; Silva-Cavalcanti, J.S.; Araújo, M.C.B.; Spengler, Â.; Tourinho, P.S. On the importance of size of plastic fragments and pellets on the strandline: A snapshot of a Brazilian beach. Environ. Monit. Assess. 2009, 168, 299-304. [CrossRef] [PubMed]

79. Jayasiri, H.; Purushothaman, C.S.; Vennila, A. Plastic litter accumulation on high-water strandline of urban beaches in Mumbai, India. Environ. Monit. Assess. 2013, 185, 7709-7719. [CrossRef] 